\title{
Influence of School Support in the Use of Computers in Teaching and Learning Biology in High Schools
}

\author{
Joseph Osodo ${ }^{1}$ \\ Israel Kibirige ${ }^{1^{*}}$ \\ David Otieno Omollo² \\ University of Limpopo, Polokwane, South Africa ${ }^{1}$ \\ Maseno University, Kenya² \\ *Email: Israel.Kibirige@ul.ac.za
}

Doi:10.5901/mjss.2014.v5n3p467

\begin{abstract}
Information Communication Technology (ICT) is intended to enable teachers to facilitate learning. However, ICT use in Biology has not been effective in Kenya. Despite the use of ICT, performance in Kenya Certificate of Secondary Education (K.C.S.E.) Biology examination mean scores dropped from 6.70 to 4.10 between 2007 and 2009. It is not clear how school support (SS) influences the use of ICT in Biology. Therefore the purpose of this study was to assess the influence of SS in the use of ICT in secondary schools in Kenya. Purposive and saturated sampling was used to select 316 Form Four students, 8 teachers, 4 principals, and 1 District Quality Assurance Officer (DQASO). A descriptive survey design was used. Data were collected using questionnaire, interview schedule and document analysis guide. Results show that SS of ICT use in Biology was weak (mean $=1.72$ ) in motivation, implementation policy, in-service training, ICT provisions and school administration and their implications are discussed.
\end{abstract}

Keywords: School Support, Information and Communication Technology, Biology

\section{Introduction}

Literature on academic growth stresses the importance of school-related support in developing commitment to educational change (Hopkins \& Reynolds, 2001). This confirms Peterson's (1995) assertion that school environments are reward-scarce settings for professional work and often seem to work against teachers' best efforts to grow professionally and improve student learning. Similarly, Fullan (2001) reported that educational changes benefit from a supportive environment. In this sense, administrators' roles are crucial in creating conducive environments which help teachers to incorporate ICTs in teaching biology. ICTs in schools should lead to significant pedagogical outcomes, beneficial for both students and teachers (Ofsted, 2002; European Commission, 2004). It is on this basis that this study focussed on the following aspects of SS: staff motivation, school ICT implementation policy, training in ICT use and provision of computer accessories to determine their efficacy with respect to ICT use in the implementation of secondary school Biology curriculum.

The use of ICTs such as computer technology and internet enables teachers to facilitate learning more effectively and enhances students' understanding of concepts and improved examination outcomes. However, in Biology, their use has not produced expected outcomes in schools which offer Computer Studies in Rachuonyo South District where average performance of students in K.C.S.E. Biology examinations dropped from 6.70 to 4.10 mean between 2007 and 2009 despite the adoption of computer technology in 2005. It is not clear how SS determines students' performance in K.C.S.E biology examinations. There was therefore, need to assess SS as a determinant of use of computers in the implementation of secondary school Biology curriculum in schools which offered Computer Studies. The specific objectives of this study were to:

i. find out the aspects of SS to computer use that teachers of Biology needed in the implementation of Biology curriculum,

ii. establish the level of SS on computer use given to teachers of Biology,

iii. determine the frequency of computer use in teaching of Biology lessons and 
iv. find out the relationship between teachers' frequency use of computer in teaching Biology and the level of SS.

\section{Methodology}

\subsection{Research Design}

This study employed both descriptive survey and correlation designs. Descriptive survey was used to gather information on the kind of SS of computer use by teachers in the implementation of Biology curriculum. Fraenkel and Wallen (1993) indicate that surveys are conducted to describe characteristics of a population. Correlation study design was used to determine relationship between level of SS of computer technology and frequency of use of ICTs in teaching Biology lessons (Cohen, Manion \& Morrison, 2000).

\subsection{Participants}

Purposive sampling technique was used to select secondary schools which offer computer studies as an examinable subject while saturated sampling technique was used to select the participants which included 1 DQASO, 4 principals, 8 Biology teachers, and 316 Form 4 Biology students from four secondary schools (Table 1). The researcher used purposive sampling technique because it allows the selection of sampling units subjectively so as to obtain a sample that is representative of the population (Nachmias \& Nachmias, 2005). The researcher also used saturated sampling technique because the population was manageable (Gall et al. 2007). Thus, all members were taken as a population, but the sample was less than the population because some members were used in the pilot study and therefore were not included in the study sample (Table 1).

Table 1: Population Sample Frame.

\begin{tabular}{lccc}
\hline \multicolumn{1}{c}{ Subjects } & $\begin{array}{c}\text { Population } \\
(\mathbf{N})\end{array}$ & $\begin{array}{c}\text { Sample } \\
(\mathbf{n})\end{array}$ & $\begin{array}{c}\text { Percentage } \\
(\%)\end{array}$ \\
\hline DQASO & 2 & 1 & 50.0 \\
Principals & 5 & 4 & 80.0 \\
Biology Teachers & 9 & 8 & 88.9 \\
Form four Biology students & 351 & 316 & 90.0 \\
\hline
\end{tabular}

\subsection{Instruments}

Three instruments used in this study included: questionnaire, interview schedule and document analysis guide. A Likerttype scale questionnaire had 5 points ranging from SA- Strongly Agree, A-Agree, U-Undecided, D-Disagree to SDStrongly Disagree. A total of 18 Likert-type items were used to determine the level of SS after categorizing them into the following aspects: Staff motivation, School computer policy, ICT in-service and Training and provision of ICT accessories. To ascertain its face validity the questionnaires was assessed by 2 experts: the classroom teacher and a university lecturer. Pilot studies were carried out on 1 DQASO, 1 principal, 1 teacher and 35 students of Biology who formed 10\% of the population that were not part of the sample (Hopkin, 2000). For internal consistency the results yielded an alpha level of 0.76 for teachers' questionnaire and 0.72 for students' questionnaire. These values were high enough to consider the instruments as reliable (Gay, 1987). Interview Schedule like the questionnaire was subjected to 2 experts for face validity and for reliability questions were given to one teacher to answer and sections that were not clear were amended for clarity. Finally, document analysis guide was used to corroborate the findings from the two instruments. The use of more than one instrument (triangulation) was used as a way of reducing uncertainty in interpretation of results, as recommended by Nkapa (1997).

\subsubsection{Interview Schedule}

Principals' interview schedules were used to collect information related to kinds of SS of computer technology given to teachers towards the implementation of Biology curriculum. 


\subsubsection{Document Analysis Guide}

This was used to gather information related to organization of the school, availability of and accessibility to computers within the school, teachers' computer qualifications and SS towards integration of ICTs in Biology curriculum. Document analysis included e-syllabus for Biology, teachers' guide book, Biology K.C.S.E examination results, schemes of work, and inventory record books.

\subsection{Data collection}

Questionnaires were used to collect data from teachers and students while the interview schedules were used to collect data from the principals and DQASO. For questionnaire, students and teachers of Biology were asked to list down support that they thought would enable them to use computers effectively. In the interview, principals and DQASO were asked to state aspects of SS that they would give teachers to use computers in order to effectively implement the biology curriculum. The researchers obtained research authorization from the National Council for Science and Technology (NCST), Kenya. To seek their consent, the researchers explained the purpose of the study and the implication of participation to the respondents. All the respondents consented to participate in the study.

\subsection{Data Analysis}

Quantitative data were analysed using descriptive statistics: frequency counts, percentages, means and standard deviations. The five response in the Likert scale for positively stated items, the score values were assigned as follows: Strongly Agree $(S A)=5$, Agree $(A)=4$, Undecided $(U D)=3$, Disagree $(D)=2$ and Strongly Disagree $(S D)=1$. However, for the negatively stated items, the scoring was reversed and scores assigned as follows: $S A=1, A=2,(U D)=3, D=4$ and $\mathrm{SD}=5$. A mean score of below 2.5 was treated as weak, 2.5 to 3.4 was treated as moderate while 3.5 to 5 were treated as strong dimensions. Pearson's Product Moment Correlation Coefficient was also performed to test statistically significant relationships between the levels of SS of computer use. Multiple regression analysis was carried out to determine the degree of magnitude of the relationship between the levels of aspect of SS and frequency of use of computers in teaching Biology. Qualitative data were transcribed and analyzed into categories relevant to the research objectives.

\section{Results and Discussion}

\subsection{Aspects of SS on Computer Use}

Support required by teachers varies in type and extent, for instance, pedagogical ICT co-ordination, management and leadership (Fullan, 2001). Based on guidelines for ICT implementation and integration in schools, results from the responses were organized into themes and the following aspects emerged: Staff motivation, School computer policy, computer in-service training, and provision of ICT accessories (Table 2).

Table 2: Aspects of SS on Computer Use.

\begin{tabular}{cccc}
\hline Aspect & Respondent & Frequency & Percent \\
\hline Motivation in ICT Use & Student & 200 & 63.3 \\
& Teacher & 8 & 100.0 \\
& Principal & 3 & 75.0 \\
School Computer Implementation Policy & Student & 254 & 80.3 \\
& Teacher & 8 & 100.0 \\
& Principal & 1 & 25.0 \\
Computer In-service Training & Student & 154 & 48.7 \\
& Teacher & 8 & 100.0 \\
Provision of ICT Accessories & Principal & 3 & 75.0 \\
& Student & 316 & 100.0 \\
& Teacher & 8 & 100.0 \\
& Principal & 4 & 100.0 \\
\hline
\end{tabular}


All the teachers (100\%) and a majority of principals (75\%) stated that aspects of SS of computer use were necessary. However, only $25 \%$ of the principals felt that teachers needed school computer implementation policy. It was worth noting that hardly half of the students (48.7\%) stated that teachers needed computer in-service training. This could be attributed to the fact most students regard their teachers as custodians of knowledge. Those who felt teachers needed in-service training in computers could be those who take computer studies and had more skills and knowledge in computers than some of their teachers. It is also observable from Table 2 that more than $60 \%$ of students felt that teachers needed motivation, school computer implementation policy and more ICT accessories in order to teach more efficiently and effectively. Responses from DQASO on the same question confirmed teachers' feelings that the school should provide support to teachers, more especially in the above aspects of support.

\subsection{Aspects of School Support of Computer Use}

Teachers and principals were asked to state the extent to which they agreed with given statements on SS with respect to computer use in the implementation of Biology curriculum in their respective schools (Table 3).

Table 3: School Support of Computer Use.

\begin{tabular}{|c|c|c|c|c|}
\hline Aspects of Support & Respondent & Number & $(\bar{X})$ & Level of Support \\
\hline \multirow{2}{*}{ Teacher Motivation } & $T$ & 8 & 2.48 & Weak \\
\hline & $P$ & 4 & 3.0 & Moderate \\
\hline \multirow{2}{*}{ School Computer Policy } & $\mathrm{T}$ & 8 & 1.5 & Weak \\
\hline & $P$ & 4 & 1.5 & Weak \\
\hline \multirow{2}{*}{ Comp. In-service Training } & $\mathrm{T}$ & 8 & 1.5 & Weak \\
\hline & $P$ & 4 & 1.5 & Weak \\
\hline \multirow{2}{*}{ Provision of ICT Accessories } & $\mathrm{T}$ & 8 & 1.5 & Weak \\
\hline & $\mathrm{P}$ & 4 & 1.8 & Weak \\
\hline \multirow{2}{*}{ Total } & $\mathrm{T}$ & 8 & 1.72 & Weak \\
\hline & $\mathbf{P}$ & 4 & 1.96 & Weak \\
\hline
\end{tabular}

Key: $T=$ Teacher, $P=$ Principal

\subsection{Teacher Motivation in Computer Use}

When people are motivated to learn, they begin the tasks enthusiastically, work longer and harder than when they are not (Fullan, 2001). It was in this context that respondents were asked to rate their level of agreement on motivationbased statements. As seen from Table 3, the mean score of teachers on staff motivation as an aspect of SS given to teachers was 2.38, which was categorized as weak. It was worth noting that principals' mean score on the same aspect was higher $(\bar{X}=3.00)$ implying that there was moderate support. However, DQASO seemed to support the teachers' opinion that staff motivation to use computers in implementing Biology curriculum was weak. The DQASO made the following comments:

"Teacher motivation with respect to ICT use is generally weak in many schools since most of the secondary schools in the district do not walk the talk of ICT integration in teaching curriculum subjects. Generally, they do not give it a priority in their annual budget even though they do say ICT use, especially in management purposes, is beneficial".

Document analysis carried out by the researcher indicated no evidence that teachers were motivated to use computers in implementing Biology curriculum. Generally, results revealed that the level of staff motivation, as a form of SS given to teachers of Biology by their respective schools, was weak. This finding may be attributed to the fact that many principals in secondary schools have not fully embraced the use of computers in teaching and learning processes since most of them have minimal ICT skills and knowledge, a low level of ICT resources available as evidenced by low computer to student ratio (1: 162) and lack of on-site technical support. The findings concur with Cox, Preston and Cox (2000) who reported that the level of resources available is one of the factors influencing teacher motivation, and that there is a positive relationship between the level of resources available and teacher motivation. Based on Cox and colleagues' (2000) findings, it can be argued that school administrators need to provide adequate computers in order to motivate teachers. Omusonga (2009) also holds the same view. The research findings are also in agreement with earlier 
research findings by Kozma, McGhee, Quelllmalz and Zalles (2004) that lack of incentives and support to teachers hinder effective use of ICT. This study found that teachers enthusiastically engage in collaborative projects and often portray a constructivist's pedagogy when they use ICT in teaching. Constructivists believe that knowledge is generated by learners through experience-based activities rather than directed by instructors (Robler, 2006). Another study carried out by Tinio (2010) concluded that leadership plays a key role in computer integration in education and that many teachers' or students' initiated projects have been undermined by lack of support from education administrators. For computer integration programs to be effective and sustainable, administrators themselves should be competent in the use of the technology. These findings support the current study findings that there was a weak level of motivation given to Biology teachers by their respective schools in their bid to use ICT in the implementation of Biology curriculum. This could be attributed to lack of adequate skills and knowledge by school principals as revealed by study findings.

A study by Sicilia (2005) found that technical problems such as waiting for websites to open, failing to connect to the internet, printers not printing, malfunctioning computers and teachers having to work on old computers impeded smooth delivery of lessons and the natural flow of the classroom activities, hence these are major barriers to teachers. The study further found that whatever kind of technical support and access teaching staff have and whether they have twenty years of experience or are novices to the profession, technical problems generate barriers to the smooth delivery of biology lessons by teachers. This is confirmed in the current study findings that the level of staff motivation was generally weak, hence a major hindrance to teachers' use of ICT in class. This explains the low frequency of use of ICT in implementing Biology curriculum in the selected schools. This finding implies those teachers need real time-technical support in resolving problems related to hardware, software and computer networks; problems that often interfere with learning.

Availability of on-site technical support encourages teachers to use computers in implementing Biology curriculum. If there is lack of technical support available in schools, then it is likely that technical maintenance would not be carried out regularly, resulting in a higher risk of technical breakdowns. Such technical faults might discourage teachers from using computers in their teaching because of the fear of equipment breaking down during a lesson causing teachers to lose confidence. Lewis (2003) contends that without both good technical support in the classroom and whole school resources, teachers cannot be expected to overcome the barriers preventing them from using ICT. An earlier study by Pelgrum (2001) found that among primary and secondary teachers', one of the top barriers to ICT use in education was lack of technical assistance. This confirms the current study findings that over $80 \%$ of the computers were non-functional due to technical problems.

\subsection{Training in ICT}

From Table 3, it is clear that with regard to school sponsorship of teachers for training in computer use, teachers and principals each had a mean score of 1.5, categorized as weak. An interview carried out with DQASO by the researchers support results obtained from teachers and principals. From the interview it was clear that teachers generally lacked training in computer use. Similar results were revealed by document analysis; that only one school (12.5\%) had one teacher sponsored for Kenya Education Staff Institute (KESI) ICT training, while the rest (87.5\%) had not. It is clear that most of the teachers had not been trained in computer use and hence lacked the necessary skills as well as pedagogical knowledge for integrating computers in teaching and learning Biology. This explains the low use of computers in teaching Biology as revealed by this study. Also, lack of sponsorship may be attributed to the fact that computer courses are charged exorbitantly in Kenya and that most schools have not given it the priority it deserves. This finding is supported by a research study finding by the Commonwealth of Learning (CoL) (2004) that, training opportunities have remained limited in availability and inconsistent in quality. This CoL report pointed out that the prohibitive cost of training teachers to use computers and the shortage of public funds to devote to this are fundamental challenges to be overcome before ICT capacity building can become a reality in Kenyan education.

To effectively introduce technology into schools is largely dependent upon the provision of ICT resources such as hardware, software and communications infrastructure. If ICT resources cannot be accessed by the teacher, as in so many education settings in Sub-Saharan Africa (SSA), then it will not be used (Hennessy, et. al 2010). Based on this assertion and the fact that school principals are charged with the responsibility of sourcing and availing teaching/learning resources, the respondents were asked questions related to provision of ICT resources by their school administrations. The results indicated that teachers and principals had a mean score of 1.5 and 1.75 respectively on this aspect. These fell in the category of weak support. The findings may be attributed to exorbitant cost of some ICT software and hardware, general lack of ICT policy hence ICT accessories provision have not been considered as a priority. Lack of 
interest by school principals in the use of ICT in teaching and learning process is also a challenge. The findings were in agreement with those of Omusonga (2009), Leng (2008), Mwaniki et al (2007), Wekesa (2003) and Cox et al. (1999) that effective leadership by principals is critical for successful integration of ICT in schools so as to take advantage of the potential of ICT. This could be because ICT involves decision making, influencing others, clear principals' vision for the schools and communicating that vision to both teachers and students, supporting its achievements by giving instructional leadership and resources (Omusonga, 2009).

\subsection{Frequency of ICT Use for Teaching Biology}

Concerning frequency of computer use for teaching Biology lessons, teachers were asked to state frequency of their access to computers for teaching Biology in hours per term in their schools. They were to choose from a list of times that best applied to their school situation. The results obtained showed that most of the teachers (87.5\%) reported that they had access to computer resources for teaching Biology between 0-5 hours per term. It was surprising to note that only one teacher (12.5\%) reported that he had access for between 6-10 hours per term. Students confirmed their teachers' responses as indicated in Table 4.

Table 4: Frequency of access by teachers to computers for biology.

\begin{tabular}{cc}
\hline Number of hours & Percentage (\%) \\
\hline $0-5$ & 69.60 \\
$6-10$ & 15.80 \\
$11-15$ & 7.90 \\
$16-20$ & 4.70 \\
21 and above & 1.90 \\
\hline
\end{tabular}

Results obtained from principals' responses concerning frequency of ICT use revealed that majority of the teachers (69.60\%) had access to computers for between $0-5$ hours while only one (15.80\%) said that teachers had access for between 6-10 hours (Table 4). Most principals reported that teachers rarely used computers, as an aspect of ICT, in teaching biology. This implied that the frequency use was very low. Analysis of schemes and records of work used by biology teachers revealed that only two teachers had used computers for biology. The rest of the teachers did not record how they accessed computers in either schemes of work and record of work. Hence it was difficult to determine their access in hours per school term despite claims that they occasionally used ICT. This finding could be due to the fact that the Kenya National Curriculum for Secondary School published in 2003 stipulates activities to be carried out by the teachers, but does not include any ICT- integrated activity and teachers tend to limit themselves to the stipulated activities. This may also be attributed to lack of training and expertise in computer use. This view is concurrent with Schnittka and Bell's (2009) view that lack of adequate pedagogical knowledge and skills limit pre-service biology teachers' use of interactive display systems to support reforms-based science instruction. The findings also concur with the earlier findings by Mumtaz (2000), Pelgrum (2001), Hawkins (2002), Empirica (2006), Toprakci, (2006), World Bank (2006) and Korte and Hüsing (2007), which indicate that lack of access to ICT resources discourages teachers from integrating new technologies into science education.

\subsection{Relationship between teachers' frequency of computer use and level of school support}

The relationship between the teachers' frequency of computer use in teaching biology and level of school support of computer use is reported in Tables 5 and 6.

Table 5: Summary of the influence of independent variables on frequency of ICT use in teaching Biology.

\begin{tabular}{ccccc}
\hline Model & $\mathbf{R}$ & $\mathbf{R}$ Square & Adjusted R & Standard Error of the Estimate \\
\hline 1 & .96 & .92 & .80 & .16 \\
\hline
\end{tabular}

From Table 5, the correlation coefficient $(\mathrm{R})$ between criterion variable $(\mathrm{y})$ and the linear combination of the predictor variables was 0.96 which is a strong positive relationship between the variables. The correlation coefficient, $R=0.96$ translates into a coefficient of determination, $R^{2}=0.92$ which means that $92 \%$ of the variance in frequency of computer 
use in teaching Biology can be accounted for by the level of aspects of school support of computer use. The adjusted R square is 0.80 thus it can be said that $80.0 \%$ of the variance in the frequency of computer use in teaching Biology was accounted for by the four explanatory variables. The residual is $19.8 \%$, which may be accounted for by extraneous variables and ineptitude in data collection. The standard error of estimate is 0.16 meaning that the predicted scores deviated by 0.16 units from observed scores, which is a very small degree of error. The implication of these results is that the four predictor variables in combination are important determinants of use of computer in the implementation of biology curriculum in the sampled schools. A regression on level of provision of computer ICT accessories and frequency of use of computers in the implementation of biology curriculum gave the results shown in Table 6 .

Table 6: Regression coefficients of the level of provision and frequency of use of computers

\begin{tabular}{lccccc}
\hline Model & $\begin{array}{c}\text { Unstandardized } \\
\text { Coefficients }\end{array}$ & & $\begin{array}{c}\text { Standardized } \\
\text { Coefficients }\end{array}$ & $\mathbf{t}$ & Sig \\
\hline 1 (Constant) & Beta & Standard error & Beta & & \\
\hline Provision of ICTs & .86 & .25 & & .34 & .42 \\
\hline
\end{tabular}

From Table 6, it can be deduced that for every one point increase in the level of provision of ICT accessories, frequency of computer use increases by 0.62 points. The observed value of test statistic ( $t_{o b}=3.46, p=.04$ ) exceeds critical value $\left(\mathrm{t}_{\mathrm{cv}}=\right.$ or- 1.96). Thus, there is significant relationship between the level of provision of ICTs and frequency of use computers in the implementation of biology curriculum. The finding that there was low frequency of computer use (0-5 hours per term) and weak level of support (Mean $=1.72$ ) given to teachers of biology by the schools also support those of Guha (2003), Lewis (2003), and Korte and Hüsing (2007) who reported that there is a positive relationship between school support and ICT integration. However, findings of this study are inconsistent with those of Kumar, Che-Rose and D'Silva (2008) who reported that there was no significant relationship between ICT integration and school support. This could be attributed to the fact they used urban and semi urban schools which had adequate resources and other structural facilities in place and teachers had got used to them while in the current study, the researcher used rural schools.

\section{Conclusions}

The study established that teachers of biology needed motivation, school computer policy, in-service training in computer use and provision of ICT accessories as reported by $100 \%$ of the teachers. The study also established that the level of support given to teachers by the school administration in the use of computers was weak, with a mean score of 1.72 . Frequency of computer use was generally low (0-5 hours per term). The study further established that there was a positive correlation between teachers' frequency of computer use and level of school support. Teacher in-service training in computer use and provision of ICT accessories had the highest correlation. Thus, it may be concluded that the level of school support is a determinant of computer integration into Biology curriculum and the variable level of provision of ICT accessories is a statistically significant predictor of frequency of computer use in teaching Biology. It is recommended that appropriate measures be taken to support teachers to enable them to use computer technology. School administrators should motivate teachers, put in place school computer implementation policy, provide more computer accessories and sponsor teachers for training in computer use.

\section{References}

Adesote, S. A. \& Fatoki, O. R. (2013). The Role of ICT in the Teaching and Learning of History in the 21st Century. Educational Research and Reviews, 8(21), 2155-2159.

British Education Commission and Technology Agencies (Becta). (2004). A Review of Research Literature on Barriers to the Uptake of ICT by Teachers. Retrieved September 3, 2010.

Cohen, L. Manion, L. \& Morrison, K. (2000). Research Methods in Education. London: Croom Helm Ltd.

Commonwealth of Learning. (2004). Towards a Strategy on Developing African Teacher Capabilities in the Use of ICT. IICD Draft Report.

Cox, M., Preston, C. \& Cox, K. (1999). What Motivates Teachers to Use ICT. A Paper Presented at British Education Research Association Annual Conference. University of Sussex at Brighton, September, 1999.

Fraenkel, J. R. \& Wallen, N. E. (1993). How to Design and Evaluate Research in Education. New York: McGraw Hill. 
Fullan, M. (2001). The New Meaning of Education Change. (3rd Ed). London: Routledge.

Gall, D. M., Gall, P. J. \& Borg, W. (2007). Educational Research: An Introduction. (8th Eds.). New York: Longman.

Gay, L. R. (1987). Educational Research: Competencies for Analysis and Application. (3rd Ed.). Melbourne: Merrill Publishing Company.

Goktas, Y., Yildirim, S. \& Yildirim, Z. (2009). Main Barriers and Possible Enablers of ICTs Integration into Pre-service Teacher Education Programs. Educational Technology \& Society, 12 (1), 193-204.

Hayden, S. (2011). Teacher Motivation and Student Achievement in Middle School Students. ProQuest Dissertations and Theses, 2011. In http://udini.proquest.com/view/teacher-motivation-and-student-pqid:2556274561. Accessed 17/11/2012.

Hopkins, W. G. (2000). Quantitative Research Design. Sport Science. 4(1).

Idowu, A. I. \& Esere, M. (2013). ICT and Higher Educational System in Nigeria. Educational Research and Reviews, 8(21), $2021-2-25$.

Kozma, R., McGhee, R., Quellmalz, E. \& Zalles, D. (2004). Closing the Digital Divide: Evaluation of the World Link Program. International Journal of Educational Development, 25(4), 361-381.

Kumar, N., Che-Rose, R. \& D'Silva, L. R. (2008). Factors Influencing Effective Use of Technology Among Malaysia Teachers. European Journal of Social Sciences, 6(4):10.

Mwaniki, M. (2007). School Heads on their Secret of Success. Daily Nation, March 2, P.2.

Nachmias, C. F. \& Nachmias, D. (2005). Research Methods in the Social Sciences. (5 $5^{\text {th }}$ Ed). Great Britain: Hodder Arnold.

Nkapa, N. (1997). Education Research for Modern Scholars. Enugu: Fourth Dimension.

Omusonga, T. O. (2009). Implementation of French Curriculum in Secondary Schools in Western Province. Unpublished Ph.D Thesis. Maseno University, Kenya.

Osodo, J. \& Indoshi, F. (2012). Incorporation of Computer Simulations in Teaching Geography. Saarbrucken: Lambert Academic Publishing

Peterson, K. D. (1995). Teacher Evaluation: A Comprehensive Guide to New Directions and Practices. Thousand Oaks CA: Corwin Press Inc.

Robler, M. D. (2006). Integrating Educational Technology into Teaching. Upper Saddle River: Pearson Prentice Hall.

Sicilia, C. (2005). The Challenges and Benefits Teachers' Practices in Constructivists Learning Environment Supported by Technology. Unpublished Masters Thesis. Montreal.

Tinio, L. V. (2010). ICT in Education: Key Challenges in Integrating ICT in Education. Foundation of Information Technology Education and Development. FIT-ED. Macmillan: Philippines.

UNESCO. (2013). ICT in Education: A Community of Practice For Teachers in a Networked Society. UNESCO Report 2013. Accessed 17/11/2013. In http://www.unescobkk.org/ education/ict/online-resources/databases/ict-in-education-database/item/article/acommunity-of-practice-for-teachers-in-a-networked-societyl

Wekesa, G. (2003). Impact of Principal Instructional Leadership on Students' Achievement in Kenya. Unpublished PhD Thesis, Columbia University, Columbia. 